\title{
Morphotectonic Analysis along the Northern Margin of Samos Island, Related to the Seismic Activity of October 2020, Aegean Sea, Greece
}

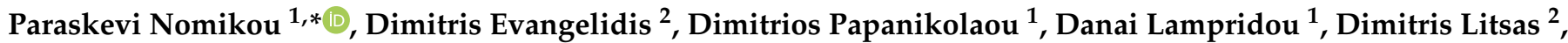 \\ Yannis Tsaparas ${ }^{2}$ and Ilias Koliopanos ${ }^{2}$
}

1 Department of Geology and Geoenvironment, National and Kapodistrian University of Athens, Panepistimioupoli Zografou, 15784 Athens, Greece; dpapan@geol.uoa.gr (D.P.); dlabgeo@hotmail.com (D.L.)

2 Hellenic Navy Hydrographic Service, Mesogeion 229, TGN 1040 Cholargos, Greece; director_hnhs@navy.mil.gr (D.E.); dimlitsas@gmail.com (D.L.); ioannis_tsaparas@hotmail.com (Y.T.); Greddy128@gmail.com (I.K.)

* Correspondence: evinom@geol.uoa.gr

Citation: Nomikou, P.; Evangelidis, D.; Papanikolaou, D.; Lampridou, D.; Litsas, D.; Tsaparas, Y.; Koliopanos, I. Morphotectonic Analysis along the Northern Margin of Samos Island, Related to the Seismic Activity of October 2020, Aegean Sea, Greece. Geosciences 2021, 11, 102. https:// doi.org/10.3390/geosciences11020102

Academic Editors: Ioannis Kassaras, Athanassios Ganas, Paolo Pace and Jesus Martinez-Frias

Received: 26 January 2021

Accepted: 16 February 2021

Published: 20 February 2021

Publisher's Note: MDPI stays neutral with regard to jurisdictional claims in published maps and institutional affiliations.

Copyright: (c) 2021 by the authors. Licensee MDPI, Basel, Switzerland. This article is an open access article distributed under the terms and conditions of the Creative Commons Attribution (CC BY) license (https:/ / creativecommons.org/licenses/by/ $4.0 /)$.

\begin{abstract}
On 30 October 2020, a strong earthquake of magnitude 7.0 occurred north of Samos Island at the Eastern Aegean Sea, whose earthquake mechanism corresponds to an E-W normal fault dipping to the north. During the aftershock period in December 2020, a hydrographic survey off the northern coastal margin of Samos Island was conducted onboard R/V NAFTILOS. The result was a detailed bathymetric map with $15 \mathrm{~m}$ grid interval and $50 \mathrm{~m}$ isobaths and a morphological slope map. The morphotectonic analysis showed the E-W fault zone running along the coastal zone with $30-50^{\circ}$ of slope, forming a half-graben structure. Numerous landslides and canyons trending N-S, transversal to the main direction of the Samos coastline, are observed between 600 and $100 \mathrm{~m}$ water depth. The ENE-WSW oriented western Samos coastline forms the SE margin of the neighboring deeper Ikaria Basin. A hummocky relief was detected at the eastern margin of Samos Basin probably representing volcanic rocks. The active tectonics characterized by N-S extension is very different from the Neogene tectonics of Samos Island characterized by NE-SW compression. The mainshock and most of the aftershocks of the October 2020 seismic activity occur on the prolongation of the north dipping E-W fault zone at about $12 \mathrm{~km}$ depth.
\end{abstract}

Keywords: swath bathymetry; submarine fault scarp; active fault; submarine canyons; submarine landslides

\section{Introduction}

Samos Island is located at the Eastern Aegean Sea near the coast with Minor Asia along the eastern margin of the Aegean plate (Figure 1). The eastern tectonic boundary of the Aegean plate with the Anatolian plate has been considered as a complex zone with strong seismicity and E-W graben structures from normal faulting [1-3], which more recently has been characterized as the West Anatolian Shear Zone with left-lateral motion based mainly on GPS data [4] (Figure 1b). The GPS displacement rate around the Samos area is $30 \mathrm{~mm} / \mathrm{yr}$ to the SW [5-7], and the geodetic strain rate displays small extension in the $\mathrm{N}-\mathrm{S}$ direction without E-W compressive component, as in the areas towards the northeast Aegean Islands such as Lesvos [8]. Seismic activity is known since the ancient times [9] and continues until today as the October 2020 events have shown.

The mainshock occurred on 30 October with magnitude $7.0[10,11]$, and its focal mechanism indicated an E-W trending normal fault dipping to the north. Its epicenter is located about 8-10 km north of Samos Island to the north of Karlovassi, situated at the basinal area of the Samos Basin [12]. The activated fault was assumed to be running along the northern margin of Samos Island, which bounds from the south the Samos Basin as the aftershock distribution also indicated (see fault plane solutions on Figure 6a). A remarkable 
tsunami, reaching a height of 1-3 m, hit the coastal areas around the Samos Basin [13], and co-seismic uplift of shorelines at the western coastline of northern Samos was observed by $10-20 \mathrm{~cm}$ [14]. A tectonic uplift of $10 \mathrm{~cm}$ was also detected from co-seismic interferometric analysis of SAR and GNSS on Samos Island [15].

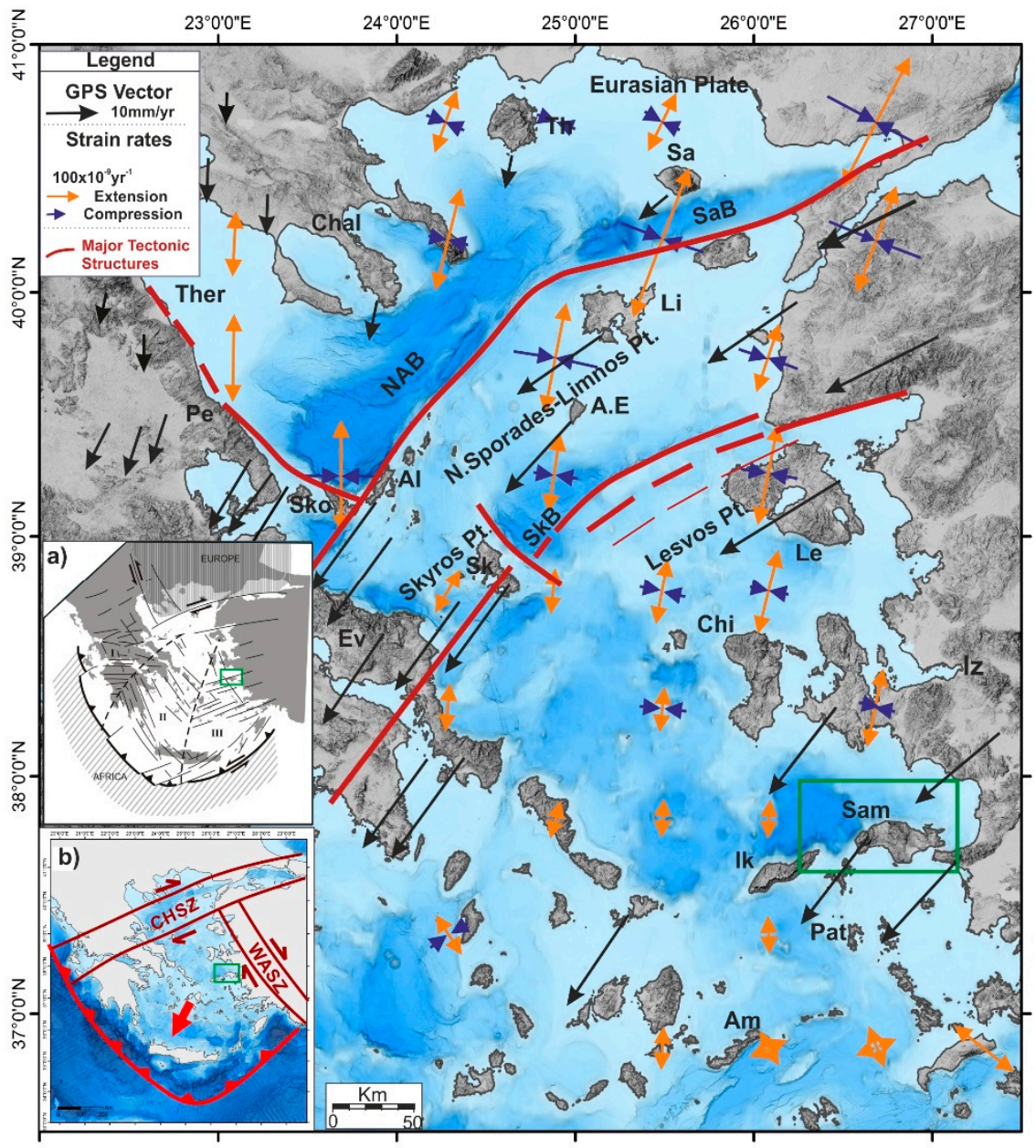

Figure 1. The location of Samos Island at the eastern Aegean Sea and the studied area in green frame. Red lines correspond to major tectonic structures and black arrows correspond to GPS vectors [16]. Orange and blue arrows correspond to geodetic strain rates [17]. A.E: Aghios Efstratios, Al: Alonnissos, Am: Amorgos, Chal: Chalkidiki, Chi: Chios, Ev: Evia, Ik: Ikaria, Le: Lesvos, Li: Limnos, Patm: Patmos, Pe: Pelion, Sa: Samothraki, Sam: Samos, Sko: Skopelos, Ther: Thermaikos, NAB: North Aegean Basin, SaB: Saros Basin, SkB: Skyros Basin, Iz: Izmir. (a) Insert map: the location of Samos at the eastern domain III of ENE-WSW neotectonic Aegean arc structure [18]. (b) Insert map: Geotectonic position of the studied area of Samos at the eastern margin of the Aegean plate, adjacent to the West Anatolian Shear Zone (WASZ) separating it from the Anatolian plate [4]. CHSZ: Central Hellenic Shear Zone.

Immediately after the seismic activity and during the aftershock period in December 2020 a hydrographic survey off the northern coastal margin of Samos Island was conducted with Hydrographic-Oceanographic Vessel R/V NAFTILOS of the Hellenic Navy Hydrographic Service, using the multibeam SeaBat 7160 RESON. The result of the hydrographic survey is presented in this paper with a detailed bathymetric map (15 m grid interval and $50 \mathrm{~m}$ isobaths) followed by the morphotectonic analysis of the obtained bathymetric data and discussion of their relation to the recent seismic activity and the active tectonics of the Samos broader area. 


\section{Geological Setting of Samos Island}

Samos Island occurs on the medial tectono-metamorphic belt of the Hellenides (former Attica-Cyclades massif) at the eastern segment of the Aegean arc, including also Ikaria Island [19]. It is characterized by E-W to ENE-WSW oriented neotectonic - morphotectonic structures, forming a wide angle with the NW-SE structures of the western segment of the Aegean arc, observed along the Evia, Andros and Tinos islands [18] (Figure 1a). Both segments comprise an alternation of tectonic horsts (represented by the islands) and grabens (represented by the interfingering gulfs and channels) occupying a back-arc position, parallel to the frontal arc structures along the Hellenic trenches. The main offshore structure in the central eastern Aegean Sea is the Ikaria basin with more than $1200 \mathrm{~m}$ of depth, whose eastern margin extends up to the NW Samos, adjacent to the smaller Samos Basin [20]. Fault plane solutions in the eastern Aegean area indicate normal faulting mainly in the E-W direction and strike-slip faulting mainly in the NE-SW direction [21]. The geological structure of Samos Island comprises several alpine tectonic units and two post alpine sedimentary basins (Figure 2) [22]. The tectonic units of the alpine basement form a nappe pile of four metamorphic and one non-metamorphic unit: (i) the Kerketeas carbonate platform at the base, representing the relative autochthon, forming a tectonic window at the western part of Samos, (ii) the Aghios Ioannis unit, the Ambelos nappe and the Vourliotes nappe occurring mainly in the central and eastern parts of the island and (iii) the uppermost non-metamorphic nappe of Kallithea, lying directly on the relative autochthon Kerketeas marbles through a late extensional detachment [23-26]. The observation of Upper Miocene granitic dikes intruding the metamorphic rocks beneath the Kallithea detachment plane within the westernmost coast of Samos Island indicates a Late Miocene-Pliocene age of the late tectonic movement [22,26].

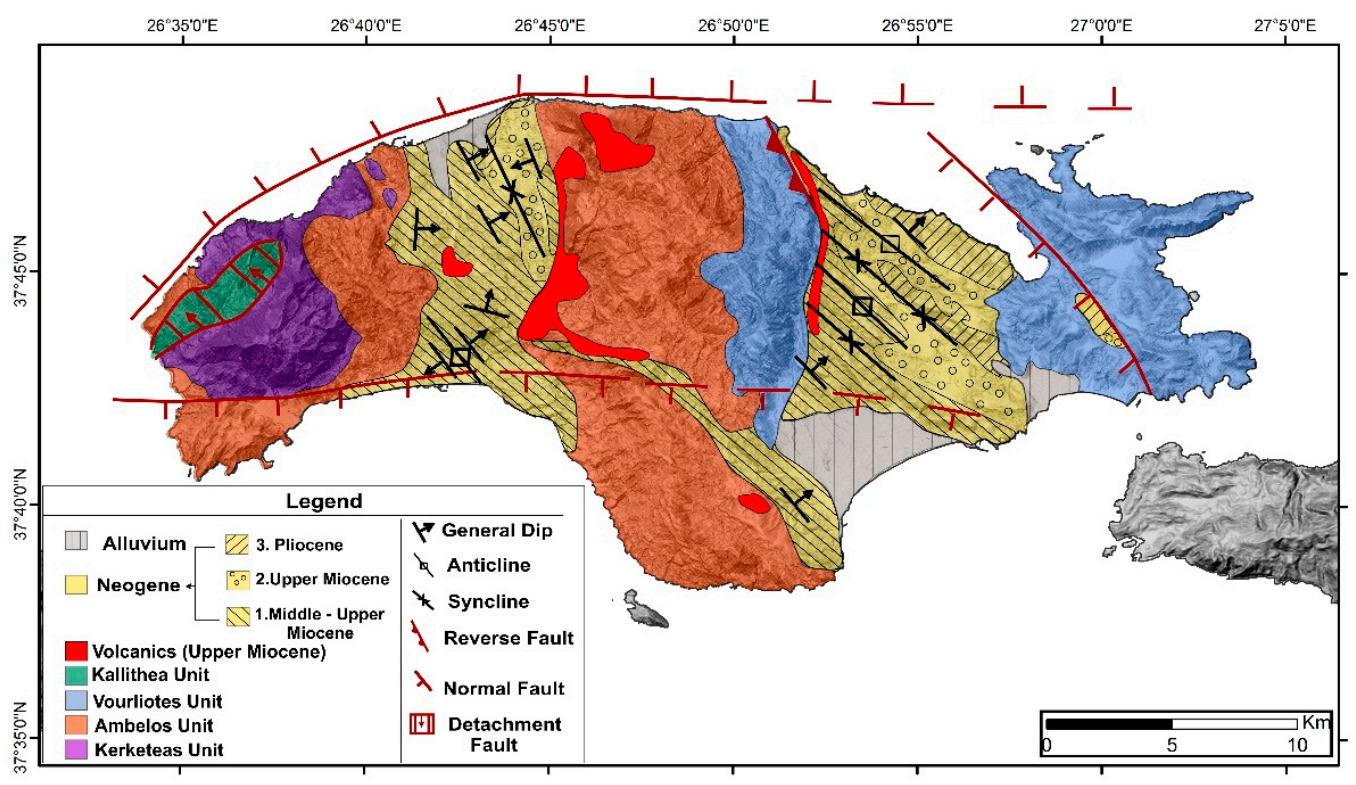

Figure 2. Simplified geological map of Samos Island [22,23].

The E-W orientation of Samos Island is the result of Quaternary deformation that created an E-W tectonic horst structure bounded by fault zones running parallel to the northern and southern coasts, respectively [27]. The northern fault zone has shaped the northern coastline with impressive outcrops of fault scarps at the western part but its trace occurs largely offshore at the central and eastern parts. The southern fault zone runs mainly onshore, forming: (i) the abrupt southern slope of the Kerketeas Mountain (1433 m) in Western Samos (ii) passes through the Neogene Karlovassi sedimentary basin (iii) continues to the east passing from southern Ambelos Mountain (1150 m) and (iv) ends at Pythagorion, bordering the Neogene sediments of the Mytilini basin to the north from the alluvial coastal 
plain to the south. Thus, the two Neogene sedimentary basins of Karlovassi and Mytilini have become inactive during the Quaternary with erosion prevailing in their outcrops' hilly landscapes.

Both Neogene sedimentary basins are bounded by N-S marginal fault structures, where volcanic rocks have intruded during the early stages of the continental sedimentation, especially along the eastern margin of the Karlovassi Basin and the western margin of the Mytilini Basin during Middle-Late Miocene [22] (Figure 2). This volcano-tectonic relation indicates the deep nature of the $\mathrm{N}-\mathrm{S}$ faults bordering the margins of the Neogene sedimentary basins, which have been initiated through E-W extension. An intra - Late Miocene angular unconformity occurs in the Mytilini Basin between the lower lacustrine formation and the middle clastic formation bearing the famous mammal fossils of the Pikermi fauna [28]. Although the early tectonic history of the two continental sedimentary basins of Samos is dominated by E-W extension with the formation of N-S trending marginal fault zones, there is a compressive event with local reverse faults and folding in the NW-SE direction [23,29] (Figure 2). The same NW-SE folding is also observed above the unconformity in the middle formation of the Upper Miocene clastics, as well as in the upper formation of the Pliocene travertines. Thus, the major change of the deformation probably occurred in Early Pleistocene, when N-S extension prevailed with E-W oriented active normal faults. The N-S extension expressed by the E-W normal faulting is actually observed in the area of the Eastern Aegean plate including the Eastern Aegean islands and the western coastal zone of Minor Asia, where $\mathrm{E}-\mathrm{W}$ trending neotectonic grabens are developed, with rivers flowing to the west such as the Great and the Lesser Meander (Buyuk and Kuyuk Menderes) [30-33]. The active tectonic horst structure of Samos Island has produced relative uplift in relation to the Samos Basin in the north and the Samos-Patmos shallow plateau in the south. However, the outcrops of the continental sediments of the Neogene Karlovassi and Mytilini basins remain at low altitudes of few hundred meters and additionally their basal unconformity on the metamorphic basement lies several hundred meters below sea level. Thus, the overall neotectonic motion is general subsidence of Samos Island and surrounding offshore areas with strong further subsidence of the northern block, creating the Samos Basin and minor subsidence of the Samos' southern block Patmos plateau. Minor Holocene uplift of Samos Island is indicated by the co-seismically raised coastlines [34]. Thus, the activated E-W striking normal fault running along the northern margin of Samos Island during the 30 October 2020 seismic event should be considered as another pulse of the ongoing active deformation since Early Pleistocene.

\section{Materials and Methods}

The data presented in this article were obtained during the oceanographic cruise onboard the Hydrographic - Oceanographic vessel NAFTILOS of the Hellenic Navy Hydrographic Service (Mesogeion 229, TGN 1040, Cholargos, Greece). The swath data have been obtained with the hull-mounted RESON SeaBat 7160, operating at $44 \mathrm{KHz}$ nominal frequency and setting the beam spacing to equidistant mode that results in the formation of 512 beams per swath. The bathymetric data were logged and further processed with TELEDYNE PDS (version 4.4.2.5) software suite and gridded at $15 \mathrm{~m}$ spatial resolution.

\section{Results}

\subsection{Bathymetry}

The main result of the hydrographic survey was a detailed bathymetric map based on a $15 \mathrm{~m}$ grid which is presented with $50 \mathrm{~m}$ contours (Figure 3). The supplementary map (Map S1) presents the Swath bathymetry map of the Samos Basin at scale 1:200,000. Samos Basin occurs north of the central part of Samos Island, with its deepest part forming a subhorizontal area with depths between $650-690 \mathrm{~m}$. This deep part of the basin is developed opposite to the Ambelos mountainous area forming the central part of Samos Island. Its southern margin towards Samos is very abrupt, and the $650 \mathrm{~m}$ isobath lies only $2-3 \mathrm{~km}$ off the coast. On the contrary, its northern margin is gradual, and the shallow isobaths of 
150-200 m occur at long distances of 15-20 km from the $600 \mathrm{~m}$ isobath. Thus, the Samos Basin geometry is highly asymmetric, and the E-W basin's axis lies parallel and very close to the northern Samos coast at an average distance of $5 \mathrm{~km}$. Its western margin, towards the deeper Ikaria Basin (more than $1200 \mathrm{~m}$ deep), lies north of the Kerketeas Mountain at Western Samos along a N-S oriented ridge of $550 \mathrm{~m}$ depth and 3-4 km width. Its eastern margin is gradual, characterized by a hummocky relief with several picks observed between the $400 \mathrm{~m}$ and $250 \mathrm{~m}$ isobaths. The length of Samos Basin along the E-W direction (from the division line at $550 \mathrm{~m}$ of depth in the west to the $200 \mathrm{~m}$ isobath north of Zoodochos Pighi in the east) is $\sim 35 \mathrm{~km}$, and its width (from the Samos coast to the $200 \mathrm{~m}$ isobath in the north) is $\sim 20-30 \mathrm{~km}$. The western part of the Samos northern coastal zone belongs to the southeastern part of the neighboring Ikaria Basin, which is much deeper and wider, extending several tens of $\mathrm{km}$ to the north. It is also remarkable that the channel separating Western Samos and Phourni Islands bisect a shallow water plateau with less than $150 \mathrm{~m}$ of depth, representing the northern exit of the broad Samos-Patmos plateau. Additionally, the overall orientation of the offshore relief and coastline in Western Samos becomes NE-SW, showing a change of orientation of more than $30^{\circ}$ from the area to the east.

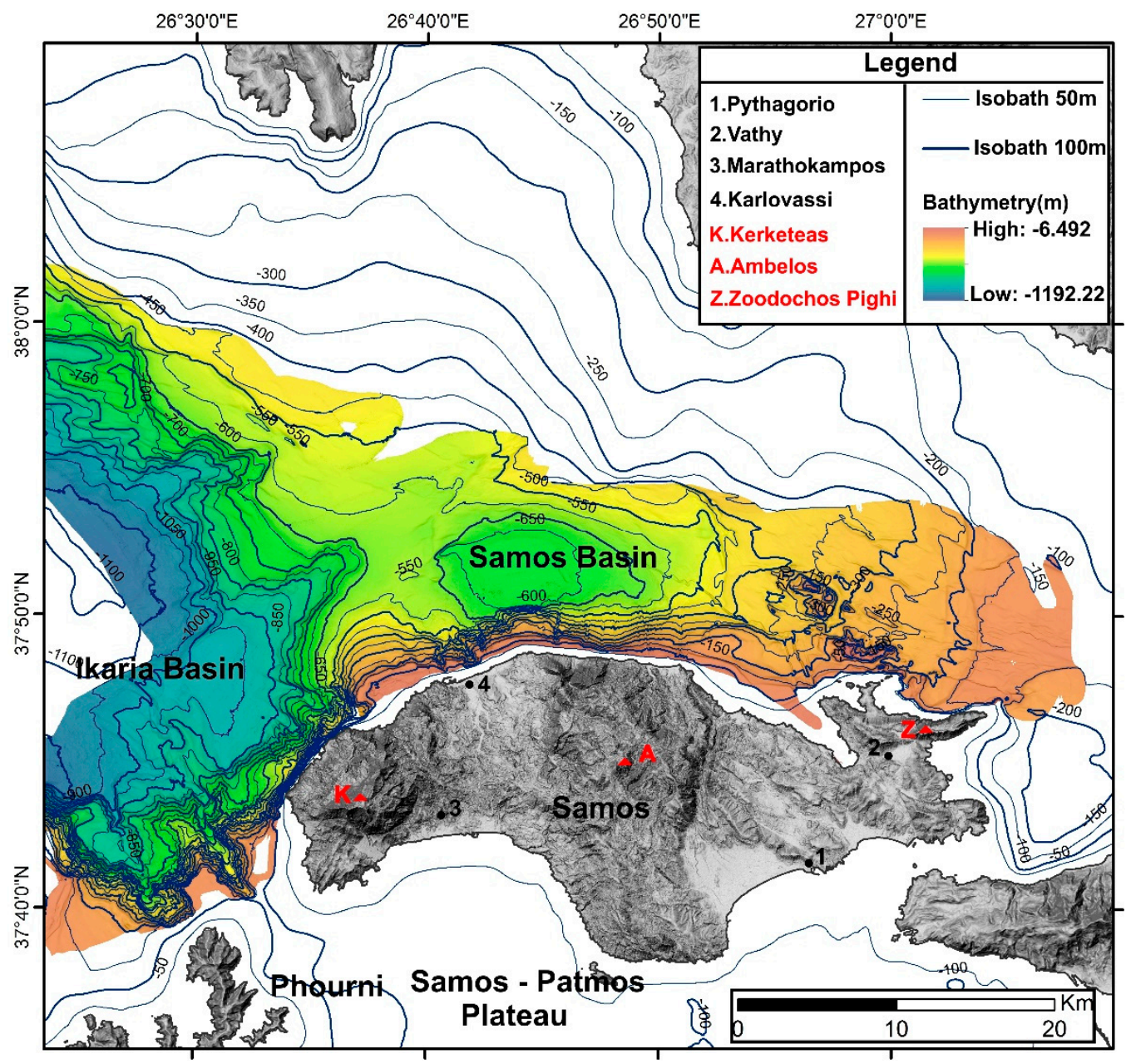

Figure 3. Detailed swath bathymetry map of the Samos Basin using $50 \mathrm{~m}$ isobaths. The surrounding offshore contours are obtained from EDMONET.

\subsection{Morphological Slopes}

The morphological slope map of the study area shows the distribution of slope values distinguished in five categories (Figure 4): (a) flat horizontal areas with slope values $0-1^{\circ}$, (b) areas with low slope values of $1-5^{\circ}$, (c) areas with medium slope values of $5-10^{\circ},(\mathrm{d})$ areas with high slope values of $10-25^{\circ}$, (e) areas with very high steep slope values $>25^{\circ}$. 


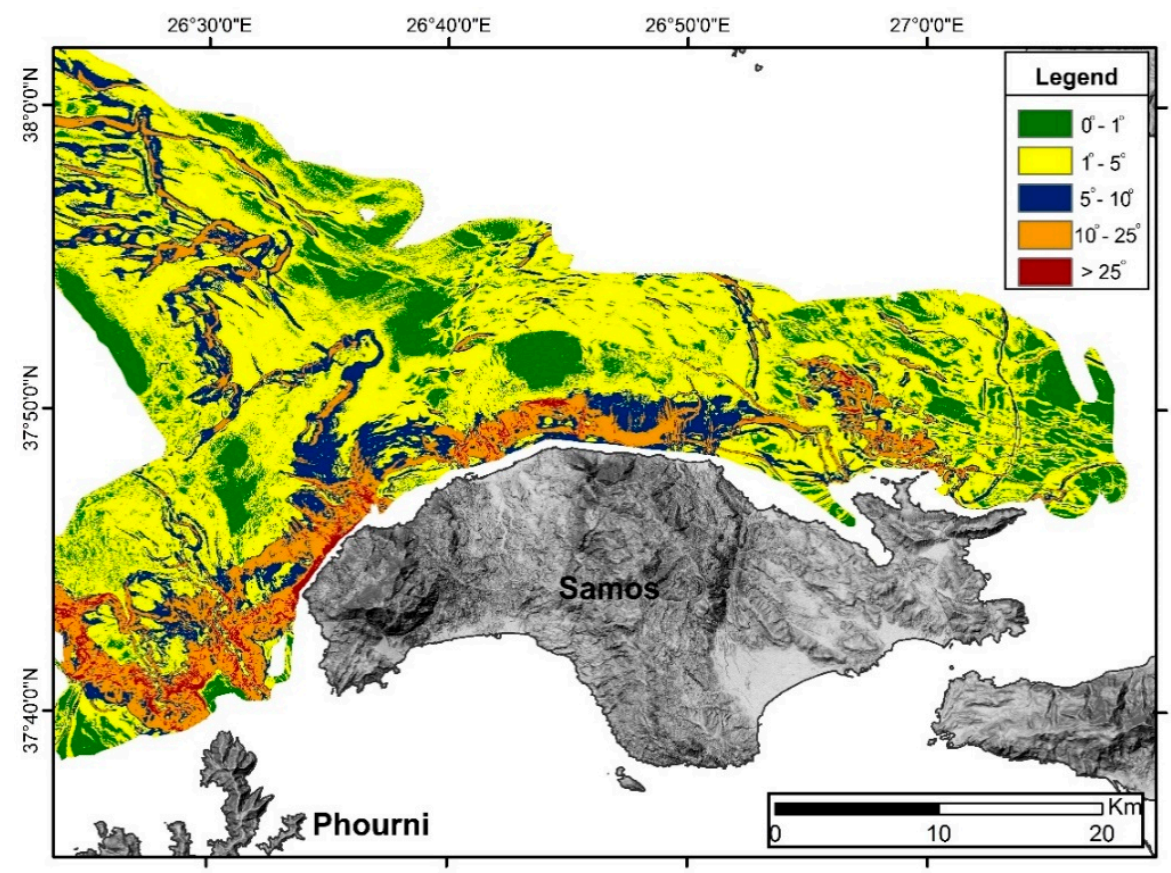

Figure 4. Morphological slope map of the studied area north of Samos Island.

The highest slope values $\left(>25^{\circ}\right)$ are observed along the northern coastline of Samos Island, forming a rather geometric narrow zone with E-W orientation at the central part and NE-SW orientation at the western part. The steep slope zone is $2-3 \mathrm{~km}$ wide bounded by the basinal depths of 550-600 $\mathrm{m}$ up to the $50 \mathrm{~m}$ isobaths at the central part and by the basinal depths of $900 \mathrm{~m}$ up to the $50 \mathrm{~m}$ isobaths at the western part. This steep slope zone corresponds to the active fault zone (see Figure 8b) bordering the Samos Basin to the south and the eastern part of the Ikaria Basin to the southwest. North of the eastern part of Samos Island the continuation of this steep slope zone is limited to a few areas with gradual decrease in slope values. Nevertheless, a chaotic, non-geometric area with high slope values oriented in various non-linear directions is observed north of the Eastern part of Samos Island.

The maximum slope values of $51^{\circ}$ have been measured at the NE-SW directed southeastern Ikaria margin at the northwestern Samos coastline, whereas $30^{\circ}$ of maximum slope values have been measured at the southern margin of the Samos Basin. A particular morphological feature observed on the slope map is a narrow zone of medium-high slopes with an irregular shape, forming submarine escarpments along the eastern margin of the Ikaria Basin. This complex escarpment zone lies between the isobaths of $650-800 \mathrm{~m}$ forming the crest line and the isobaths of 750-900 m forming the cliffs' foot zone. This feature resembles the erosional formation of cliffs created by the interlayering of a competent litho-stratigraphic formation resistant to erosion within less competent formations. In this case, the presence of a compact formation of approximately $200 \mathrm{~m}$ thickness might explain the submarine relief. Two more narrow zones with medium-high slope values are observed at the northern margin of the Samos Basin at depths between 400-500 m with a NW-SE orientation, one to the west of the division line of the Ikaria and Samos basins and the other at the central segment of Samos basin. These medium-high slope zones might represent normal antithetic faults with small throws of the order of a few tens of meters.

The sub-horizontal areas are found in basinal areas and submarine terraces (Figure 4). The basinal areas correspond to the Samos Basin with depths around $650 \mathrm{~m}$ (maximum $690 \mathrm{~m}$ ) and the eastern part of Ikaria Basin with depths around $1150 \mathrm{~m}$. Another small basin with $200 \mathrm{~m}$ depth occurs at the eastern margin of Samos Island. Two submarine terraces are observed at the western part of the studied area: (1) One deep terrace at about $900 \mathrm{~m}$ depth to the northwest of the Kerketeas Mountain, extending from the foot of the steep slope zone up to the edge of the terrace escarpment which lies at about $150 \mathrm{~m}$ above the 
basinal area of the Ikaria Basin. (2) Another terrace at about $550 \mathrm{~m}$ depth is observed along the division zone between the Samos and Ikaria basins. This terrace continues for several $\mathrm{km}$ towards the northwest with decreasing width, and its edge forms a minor escarpment of a few tens of meters. The northwestern portion of the terrace is bounded by a narrow NW-SE trending slope discontinuity zone, probably representing a normal fault.

\subsection{Morphotectonic Analysis}

The major morphotectonic structure that emerges from the bathymetric and morphological slope maps is the steep morphological slope zone, running along the northern coastline of Samos. This major structure corresponds to the submarine marginal fault zone that bounds the Samos Basin to the south and the eastern Ikaria Basin to the southeast. A 3D view of this zone is given in Figure 5 with a view from the NW. The Samos coastal zone indicates the upper limit of the marginal fault zone, whereas its lower limit lies at this zone's foot, traced by a red line. The deeper part of the basin in the central area lies opposite the Ambelos Mountain whereas the eastern margin lies opposite the much lower Zoodochos Pighi Mountain. The hummocky relief is developed just in front of the eastern coastal zone of Samos Island. Along the submarine fault scarp, there are areas where the alpine basement and the Neogene sediments crop out and other areas where the basement is covered by unconsolidated Quaternary sediments, sliding towards the foot of the scarp, forming local fans and scree deposits. Several canyons are also observed cutting through the scarp's steep slopes with mass transport from the ravines onshore. The difference between the faulted southern margin and the smooth northern margin is spectacular, illustrating the Samos Basin's asymmetric structure indicating a half-graben tectonic structure.

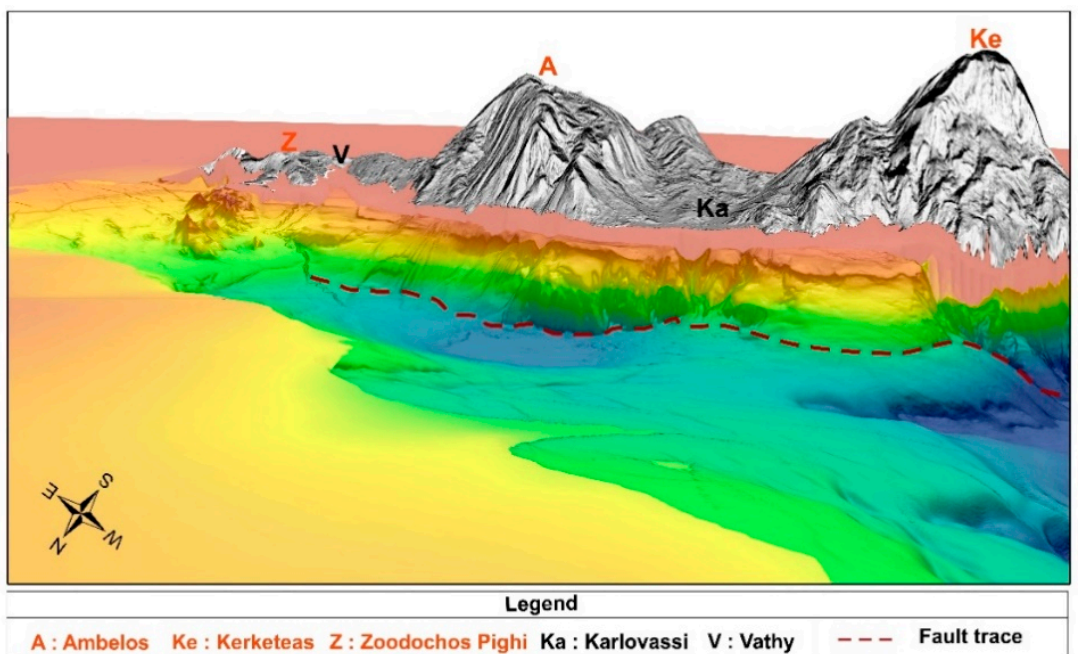

Figure 5. Panoramatic diagram of the Samos active margin. The development of the fault scarp parallel to the coastal area is impressive. At the foot of the steep slopes, the fault trace is indicated by the red line, separating it from the basinal area. The onshore relief area up to the top of the mountains is also shown. At the eastern margin of the basin the hummocky relief north of Vathy, probably representing volcanic rocks, stands out from its geometry. North of Kerketeas the relatively shallow depths mark the division zone between the Samos Basin to the east and the deeper Ikaria Basin to the west.

The specific morphotectonic structures along the northern coastal zone of Samos Island can be observed in three segments, corresponding to (a) the southeastern margin of Ikaria Basin, (b) the western part of the southern margin of Samos Basin and (c) the eastern part of the southern margin of Samos basin (Figure 6). 

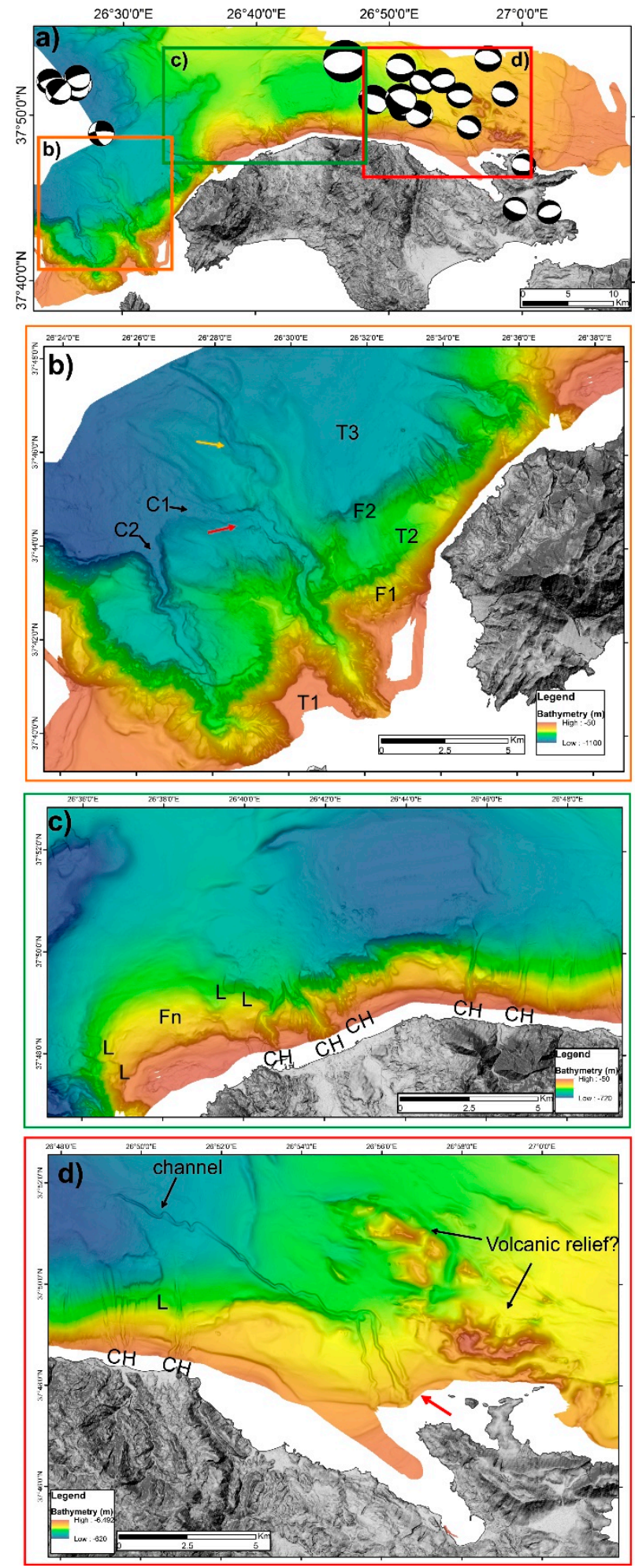

Figure 6. Detailed bathymetric maps of the northern marginal zone of Samos Island. (a) The fault plane solutions of the aftershock sequence 30 October 2020 offshore Samos Isand (from http://www.geophysics.geol.uoa.gr/stations/gmaps3/gmapv3_significant.php?mapmode= epic\&lng=el\&year $=0$ (accessed on 20 February 2021), as shown in Table S1) The three frames correspond to the detailed bathymetric maps, (b) SE Ikaria Basin, (c) W Samos Basin and (d) E Samos Basin. C: Canyon, CH: Canyon Head, Fn: Fan, L: Landslide, T: Terrace, F1, F2 faults. The colored arrows indicate special features explained in the text. 
The western part of the Samos margin faces the eastern Ikaria Basin with very abrupt slopes of more than $25^{\circ}$, with a linear trend in the NE-SW direction and a length of more than $10 \mathrm{~km}$ (Figure 6b). This steep slope zone is made of two faults (F1 and F2 in Figure 6b) separated by a narrow tectonic terrace at about $650 \mathrm{~m}$ depth. The upper fault trace lies at $650 \mathrm{~m}$ of depth bounding the tectonic terrace (T2) towards the Samos coast at a distance of only one $\mathrm{km}$ away from the coastline. The fault's plane can be followed with $50^{\circ}$ of slope up to the $50 \mathrm{~m}$ isobath, representing the steeper tectonic relief of the margin. The second fault lies along the medium-high slope zone observed west of the edge of the T2 terrace down to the deeper terrace (T3) at 900-950 m of depth. Thus, the very steep upper fault has produced a tectonic relief of more than $600 \mathrm{~m}$ height whereas the lower fault only 250-300 m. The overall tectonic relief of the NE-SW fault zone is more than $950 \mathrm{~m}$. Its continuation towards the SW is less linear but extends another $8 \mathrm{~km}$, passing through the main canyon (C1) from the Samos - Patmos plateau and draining towards the NW in the Ikaria basinal area. The canyon is very steep with high incision of more than $100 \mathrm{~m}$ of depth difference and $350 \mathrm{~m}$ width at an average. Its channeling shows local changes at distinct linear morphological zones of NE-SW direction. In between the traces of the high slope zones and the edges of the sub-planar low slope zones, we observe terrace-like forms at different depths. The same features are observed at the smaller canyon (C2) to the west, starting from the Phourni coastal area and ending at the basinal area of the Ikaria Basin to the NW. Thus, between the Samos - Patmos plateau and the Ikaria basinal area, we can distinguish submarine terraces at 100-150 m (T1), $650 \mathrm{~m}$ (T2), $900 \mathrm{~m}$ (T3) of depth and the basinal area at $1150 \mathrm{~m}$ of depth (Figure $6 \mathrm{~b}$ ). The overall structure indicates a dynamic nature with strong incision and intense mass transport from the shallow water plateau to the basinal area with a total height difference of more than $1000 \mathrm{~m}$. This dynamic nature is illustrated by the change of drainage direction of the main canyon from an older transport direction towards the NW to a new transport direction to the WNW (shown by yellow and red arrows respectively in Figure $6 \mathrm{~b}$ ). Several small canyons oriented NW-SE are observed along the steep slopes with only 3-4 km length.

The western part of the active margin of Samos Basin shows a submarine fan towards the north, forming the division line between the Samos and Ikaria basins (Figure 6c). Several canyons oriented NNW-SSE to N-S are observed between the $50 \mathrm{~m}$ isobath along which their canyon heads are aligned and the foot of the high slope zone at 600-650 m depth. The steep slope zone of the southern Samos margin is divided in two faults separated by a very narrow sub-horizontal zone/tectonic terrace at $220 \mathrm{~m}$ of depth. Thus, the Samos margin has a total tectonic relief of $650 \mathrm{~m}$ with the larger fault occurring deeper with higher slope values contrary to the Ikaria margin where the larger fault was much steeper but shallower close to the coast with a tectonic relief of more than $950 \mathrm{~m}$. These differences indicate the different nature of the two fault segments belonging to the two neighboring basins of Samos and Ikaria. Several landslides (L) are observed at both margins of the fan, separating the Samos and Ikaria basins. Their presence seems to be related to the canyons bordering the fan from both sides.

The eastern part of the Samos margin (Figure 6d) is characterized by the change of the slope with smaller slope values and more gradual transition from the shallow to the deeper parts of the basin. The perpendicular to the Samos coast canyons are observed at the western part north of the outcrops of the metamorphic rocks but disappear north of the outcrops of the Neogene sediments. The hummocky landscape forms impressive submarine relief north of the Zoodochos Pighi mountain range, contrasting the margin's geometry to the west. Another prominent feature is the twofold change of the flow direction of the channel draining the Vathy Gulf with an $S$ shape starting with a flow direction to the NW, then changing towards the E and then again turning towards the NNW (red arrow in Figure $6 \mathrm{~d}$ ) for a length of about $4 \mathrm{~km}$ and then towards the WNW for another $5 \mathrm{~km}$ up to its exit at the basinal area of Samos Basin at about $600 \mathrm{~m}$ of depth. This complicated flow line appears to be controlled by the local tectonic and geological structures with the shallow flow towards the NW following the geometry of the Vathy Gulf, which is controlled by the 
NW-SE fault passing through Palaeokastron in Eastern Samos Island (See also geological map in Figure 2).

The overall geometry of the Samos marginal fault zone can also be observed in a series of parallel sections across the margin (Figure 7). These sections generally illustrate the fault zone and the existence of one or two fault planes in different segments within the zone. The sections correspond to two distinct segments: (a) The four westernmost profiles shown in brown color (Figure 7a) correspond to the Kerketeas NW-SE oriented profiles ending at the Ikaria basinal area (black arrow I.b.) at $950 \mathrm{~m}$ of depth. (b) The other profiles to the east shown in various colors with N-S orientation end down to the Samos basinal area at $600 \mathrm{~m}$ of depth (black arrow S.b.). Eastwards, these color profiles become gradually shallower. At the easternmost profiles the hummocky relief, probably corresponding to volcanic rocks (Vo), stands out above the geometric sea bottom, forming irregular peaks at 200-300 m of depth. The main marginal fault of the Ikaria Basin is outlined with very steep slopes at the shallow depths between $50-650 \mathrm{~m}$, at a distance of $1 \mathrm{~km}$ from the coast, whereas the secondary fault occurs at $900-950 \mathrm{~m}$ of depth, at a distance of 3-4 km from the coast. The main marginal fault of the Samos Basin is observed at the deeper part of the steep slopes at about $600 \mathrm{~m}$ depth at a distance of $3.5 \mathrm{~km}$ from the coast. The difference between the NE-SW Samos margin facing the Ikaria Basin and the E-W Samos margin facing the Samos Basin is also illustrated in the profiles plotted in the 3D view of the Samos margin, viewed from the west (Figure 7b).

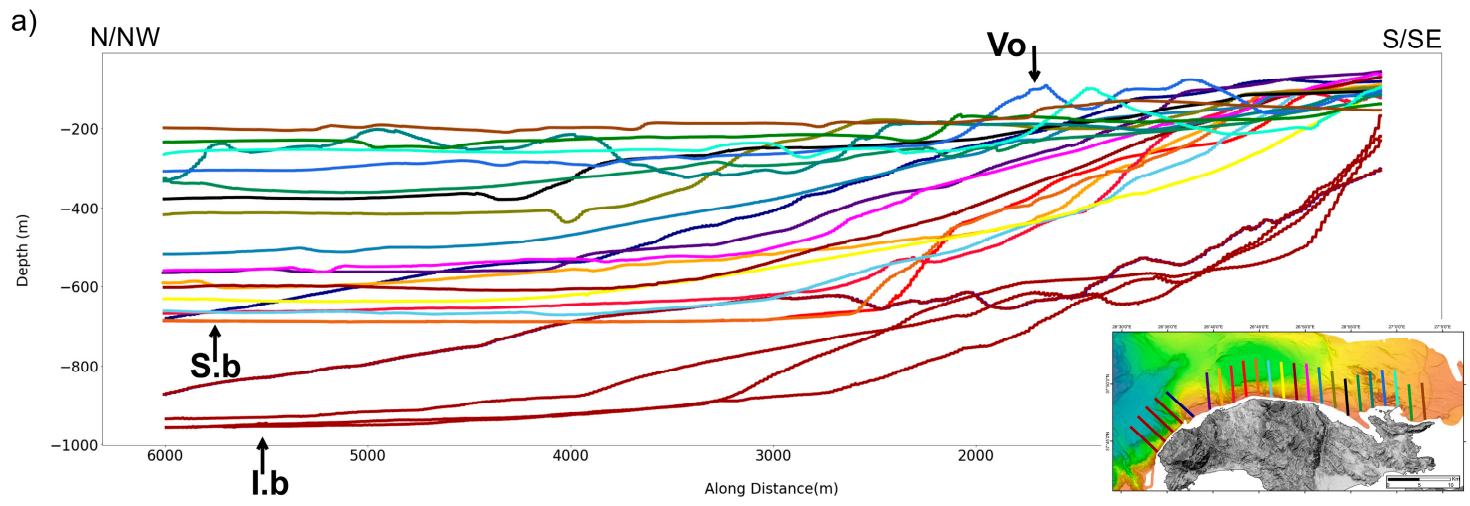

b)

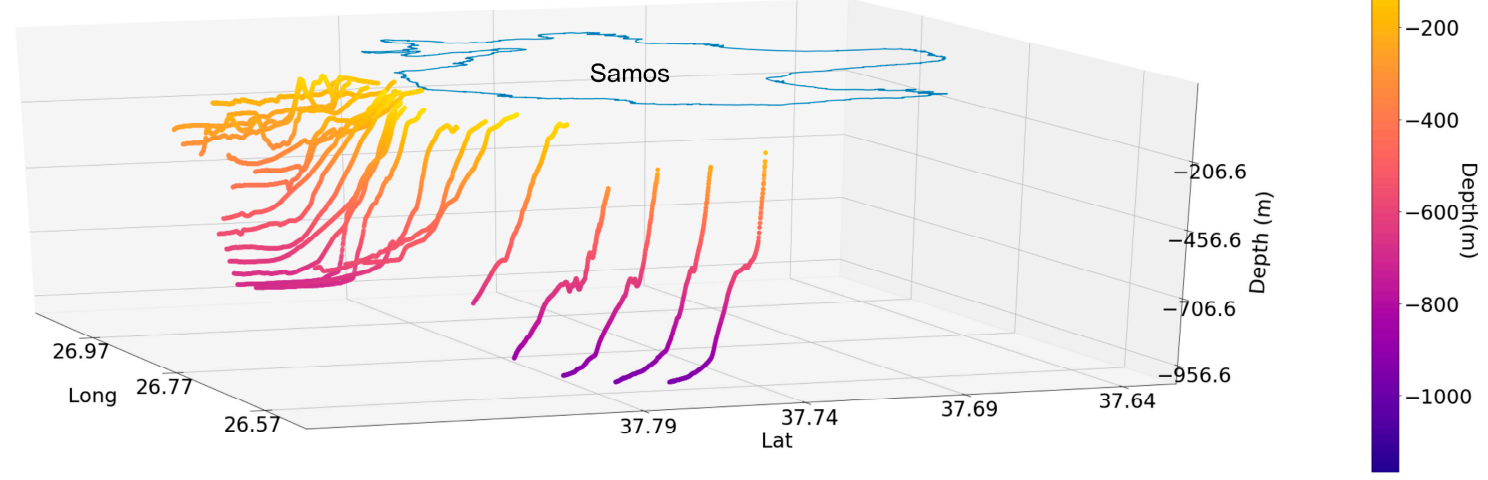

Figure 7. Parallel morphological profiles across the southern active margin of the Samos Basin. (a) Aligned profiles perpendicular to the Samos coastline. The four profiles in brown correspond to the Kerketeas NW-SE oriented profiles ending at the Ikaria basinal area (black arrow I.B.) at $950 \mathrm{~m}$ of depth. The rest profiles to the east with N-S orientation end down to the Samos basinal area at $600 \mathrm{~m}$ of depth (black arrow S.B.). The profiles show that the basin gets gradually shallower to the east. The hummocky relief stands out above the geometric sea bottom at the easternmost profiles, probably corresponding to volcanic rocks (Vo). (b) 3D view showing morphological profiles perpendicular to the Samos coastline. The deeper and steeper four profiles to the west correspond to the Ikaria Basin and the rest to the Samos basin, which gradually becomes shallower to the east. 


\section{Discussion}

The synthesis of the previously presented offshore morphological data on a morphotectonic map also combining the onshore geological data may offer an overall picture of the studied area (Figure 8a). The morphotectonic map was based on the classification of slope magnitude (Figure 4) which illustrates the zones where there is an abrupt change of slope, reflecting the possible location of active tectonic zones in contrast with areas of negligible change of slope, reflecting flat-lying areas such as submarine platforms/terraces or basinal areas. This methodology has been applied in several cases of the Aegean plate, like the North Aegean Basin and the Skyros Basin where the morphotectonic results have been verified later by lithoseismic profiling $[16,35,36]$. The first remarkable conclusion is that the onshore tectonic structure of Samos Island is very different from the offshore structure of Samos Basin. Thus, the present tectonic processes are very different from the previous tectonic and neotectonic structures. Following the NW-SE folding axes and the general dip directions of the Neogene sediments on the two Samos continental basins, we can conclude that the previous deformation was due to a compression in the NE-SW direction. This process was subsequently replaced by $\mathrm{N}-\mathrm{S}$ extension with dominant $\mathrm{E}-\mathrm{W}$ striking normal faults which controls the northern Samos coastline and the marginal fault of the Samos Basin. It is remarkable that this deformation has produced a minimum throw of $650 \mathrm{~m}$ since Early Pleistocene (based on the depth of the subsided basin) without considering the thickness of the marine Pleistocene sediments beneath the sea bottom). In the northern margin of Samos Basin, the thickness of the sediments overlying the acoustic basement is more than 1200m [37]. However, this sedimentary thickness might also represent older Neogene sediments of continental facies, like those of the onshore Samos basins and not the Quaternary marine sedimentary sequence, related to the active tectonics.

Thus, a major question regarding the neotectonic evolution of the study area is when did the area of the eastern Aegean islands become part of the Aegean Sea with marine sedimentation? The only outcrop of marine sediments in the area occurs at the southeastern part of Ikaria Island, dated as Lower Pliocene with unconformable Pleistocene submarine terraces [38-40]. On the other hand, the Kallithea detachment in West Samos and its counterparts in Ikaria (Kefala detachment) and Thymaena islands [26,40,41] indicate N-S extension already in the (?) Late Miocene-Early Pliocene.

The overall structure of the Samos Basin resembles the half-graben tectonic structure described northwards at the North Aegean Sea across the eastern Skyros fault zone [16], where $600 \mathrm{~m}$ of Middle-Upper Pleistocene sediments have been detected at the hanging wall of the ENE-WSW trending marginal fault. Similar half-graben structures have also been described in the Amorgos active fault structures in the South Aegean Sea [42], with more than 700m of Plio(?) - Quaternary sediments being detected in the hanging wall.

The hummocky relief described at the eastern margin of the Samos Basin (see Figures 3-5 and Figure 7) is known from submarine volcanic outcrops along the Aegean Volcanic arc like in the Myrtoon-Antimilos area [43] and other submarine volcanic areas [44]. It might be synchronous to the onshore Upper Miocene volcanic formations of Samos, observed along the Mytilini and Karlovassi basins (see Figure 2).

The western cluster of the aftershocks lies on the western prolongation of the major Samos seismic zone. However, its location corresponds to the NE-SW active margin of Western Samos Island belonging to the Ikaria Basin. Thus, it is not clear whether the western cluster of aftershocks is related to the Ikaria southeastern active margin or minor $\mathrm{E}-\mathrm{W}$ faults representing a continuation of the major Samos Basin fault zone. The observed difference of up to $51^{\circ}$ slope values of the NE-SW Ikaria margin compared to the up to $30^{\circ}$ slope of the Samos margin might also signify a different nature of the corresponding fault planes with strike-slip affinities in the Ikaria margin and normal faulting in the Samos margin. This interpretation is in accordance with the fault plane solutions of the broad area, where E-W normal faulting co-exists with NE-SW strike-slip faulting [21]. In any case, the activation of the much steeper marginal fault of the Ikaria Basin should correspond to epicenters located, much closer to western Samos Island. 


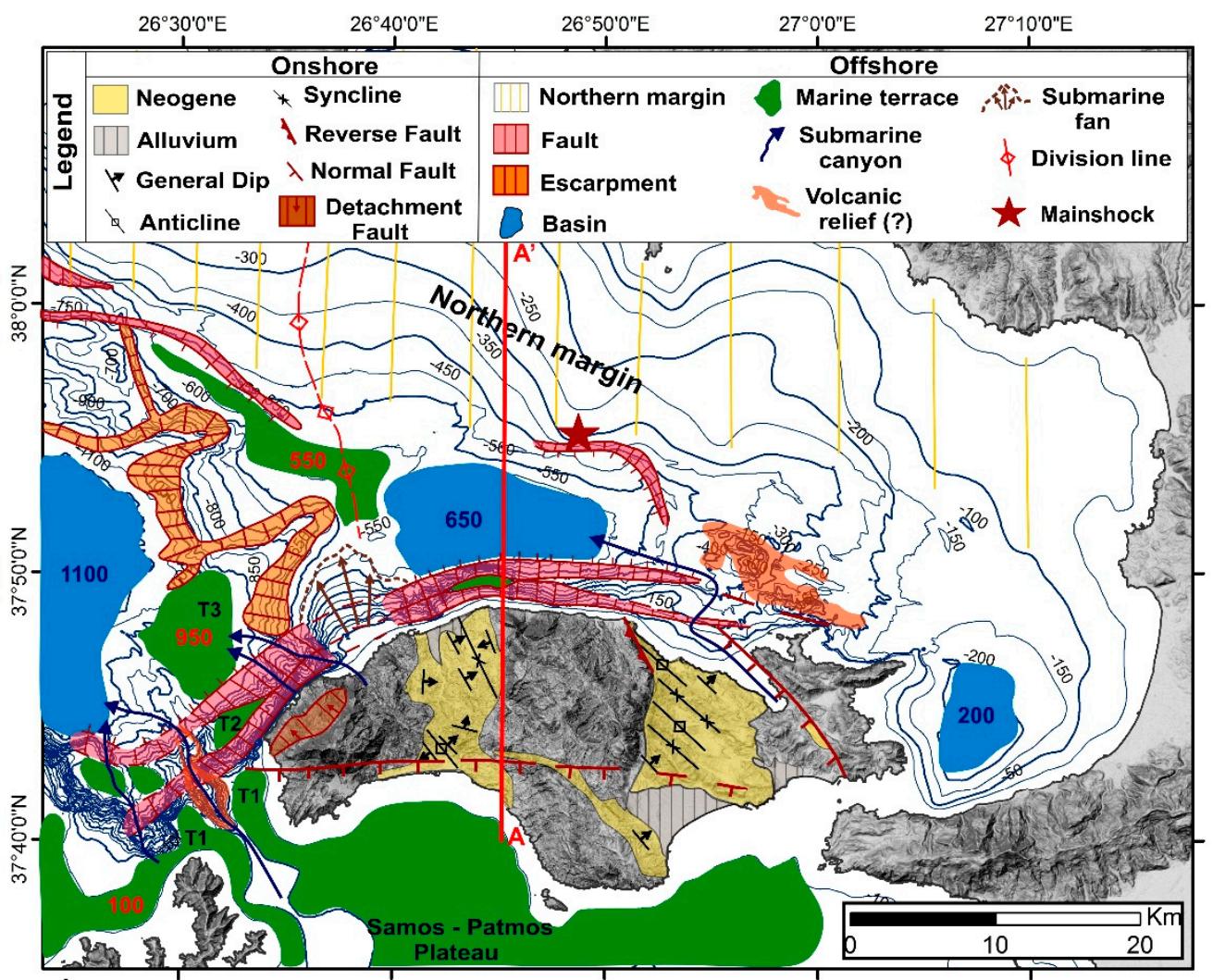

a)

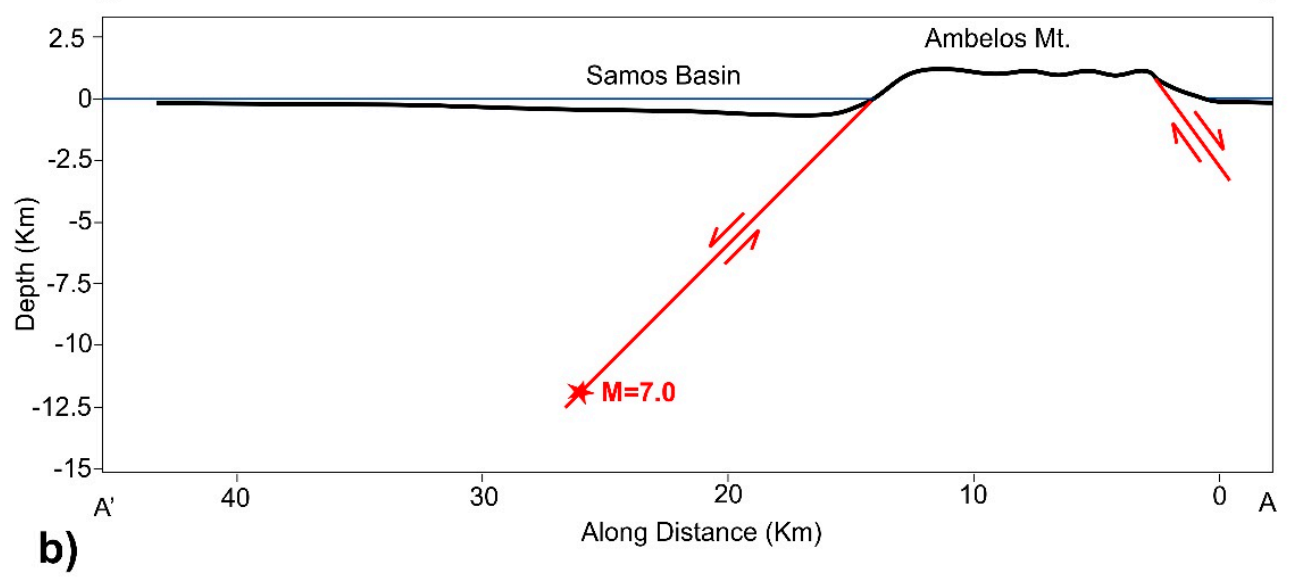

Figure 8. (a) Morphotectonic map of Samos Island and Samos Basin. (b) N-S cross section through the Samos Basin and Samos island. The E-W marginal fault is dipping to the north with $45^{\circ}$. The focus of the mainshock of magnitude 7.0 is shown at $12 \mathrm{~km}$ depth. The fault plane solutions of the October 30th seismic sequence [10] generally show E-W normal faulting (Figure 6a). The main shock (Magnitude 7.0) and most of the aftershocks (Magnitudes 5.2-3.9) occur in the central and eastern part of Samos Basin, forming a $20 \mathrm{~km}$ long seismic belt, which is smaller than expected for this magnitude (following the empirical relationships [45]). However, it is remarkable that: (i) there are no (large) aftershocks in the western part of Samos Basin, (ii) there are some aftershocks with similar plane solutions onshore in the eastern part of Samos Island, south of the major fault zone and (iii) there are some aftershocks at the eastern part of Ikaria Basin with the indication of strike-slip components besides E-W normal faulting. Thus, the aftershocks (of magnitude $>3.9$ ) indicate a "seismic gap zone" of about $20 \mathrm{~km}$ length extending from the Eastern Ikaria Basin up to the central Samos Basin. The focal depths indicate a seismic layer at a uniform level at $12-13 \mathrm{~km}$ in the activated area. Thus, the activated fault should have an average dip of $45^{\circ}$ to the north, as shown in the N-S tectonic profile through Samos Island and Samos Basin (Figure 8b). This tectonic structure is compatible with the morphotectonic analysis and the very steep slopes of the Samos margin. 
The extensional character of the asymmetric half-graben nature of the Samos Basin is documented by previous seismic events $[9,46]$. Nevertheless, N-S to NNE-SSW strikeslip structures and strike-slip fault plane solutions have been reported onshore as well as offshore in the Erythraea/Cesme Peninsula and the northern margin of the Samos Basin $[37,47]$. Such structures have not been identified in the morphology of the basin except for two secondary N-S zones at $450 \mathrm{~m}$ and $200 \mathrm{~m}$ of depth at the eastern margin (Figure 4). These minor discontinuities show an arcuate pattern, following the general geometry of the eastern margin of the Samos Basin and might reflect an earlier basin geometry.

\section{Conclusions}

In conclusion, the $690 \mathrm{~m}$ deep Samos Basin is developed north of central and eastern Samos Island whereas the much deeper with more than $1200 \mathrm{~m}$ of water depth and larger Ikaria Basin is developed north of western Samos Island. The Samos Basin is an E-W striking tectonic half-graben with abrupt slopes $\left(30^{\circ}\right)$ along its active southern margin, with more than $650 \mathrm{~m}$ of throw. The southeastern margin of the Ikaria Basin is a NE-SW oriented very steep zone $\left(51^{\circ}\right)$ with more than $1150 \mathrm{~m}$ of throw. Several canyons, landslides and fans are observed along the Samos Island margin indicate mass transport towards the north. A hummocky landscape was discovered at the Samos Basin's eastern margin, probably corresponding to volcanic edifices. The active tectonics characterized by N-S extension is very different from the Neogene tectonics of Samos Island characterized by NE-SW compression. The mainshock and most of the aftershocks of the October 2020 seismic activity occur on the prolongation of the north dipping $\left(45^{\circ}\right) \mathrm{E}-\mathrm{W}$ fault zone at about $12 \mathrm{~km}$ depth.

Supplementary Materials: The following are available online at https:/ / www.mdpi.com/2076-326 3/11/2/102/s1, Map S1: Swath bathymetry map of the Samos Basin (scale 1:200,000). Table S1: Focal mechanisms shown in Figure 6a.

Author Contributions: Conceptualization, P.N. and D.P.; Methodology, D.E. and D.L. (Danai Lampridou); Software, D.L. (Danai Lampridou) and D.L. (Dimitris Litsas); Validation, all authors; Resources, D.E.; Data Curation, D.L. (Dimitris Litsas), Y.T. and I.K.; Writing-Original Draft Preparation, D.P., P.N. and D.L. (Danai Lampridou); Writing-Review \& Editing, all authors; Visualization, D.L. (Danai Lampridou); Supervision, P.N.; Project Administration, D.P. All authors have read and agreed to the published version of the manuscript.

Funding: This research received no external funding.

Data Availability Statement: The data presented in this study are available in Map S2.

Acknowledgments: The officers and crew of the R/V NAUTILOS of the Hellenic Navy Hydro graphic Service are gratefully acknowledged. I.Mougiakos is acknowledged for his technical support. We acknowledge funding from the "RESEARCH-CREATE-INNOVATE" of the "Competitiveness, Entrepreneurship and Innovation (EPANEK)", NSRF 2014-2020, (Research project: VIRTUALDiver).

Conflicts of Interest: The authors declare no conflict of interest.

\section{References}

1. McKenzie, D.P. Plate tectonics in the Mediterranean Region. Nature 1970, 226, 239-243. [CrossRef] [PubMed]

2. McKenzie, D.P. Active tectonics of the Mediterranean Region. Geophys. J. Int. 1972, 30, 109-185. [CrossRef]

3. McKenzie, D. Active tectonics of the Alpine-Himalayan belt: The Aegean Sea and surrounding regions. Geophys. J. Int. 1978, 55, 217-254. [CrossRef]

4. Papanikolaou, D.; Royden, L. Disruption of the Hellenic arc: Late Miocene extensional detachment faults and steep PlioceneQuaternary normal faults-Or what happened at Corinth? Tectonics 2007, 26. [CrossRef]

5. McClusky, S.; Balassanian, S.; Barka, A.; Demir, C.; Ergintav, S.; Georgiev, I.; Gurkan, O.; Hamburger, M.; Hurst, K.; Kahle, H.; et al. Global Positioning System constraints on plate kinematics and dynamics in the eastern Mediterranean and Caucasus. J. Geophys. Res. 2000, 105, 5695-5719. [CrossRef]

6. Reilinger, R.; McClusky, S.; Paradissis, D.; Ergintav, S.; Vernant, P. Geodetic constrains on the tectonic evolution of the Aegean region and strain accumulation along Hellenic subduction zone. Tectonophysics 2010, 488, 22-30. [CrossRef] 
7. Müller, M.; Geiger, A.; Kahle, H.-G.; Veis, G.; Billiris, H.; Paradissis, D.; Felekis, S. Velocity and deformation fields in the North Aegean domain, Greece, and implications for fault kinematics, derived from GPS data 1993-2009. Tectonophysics 2013, 597-598, 34-49. [CrossRef]

8. Kreemer, C.; Holt, W.E.; Haines, A.J. An integrated global model of present-day plate motions and plate boundary deformation. Geophys. J. Int. 2003, 154, 8-34. [CrossRef]

9. Papazachos, B.C.; Papazachou, C. The Earthquakes of Greece; Ziti Publ. Co.: Thessaloniki, Greece, 2003; p. 286. (In Greek)

10. Papadimitriou, P.; Kapetanidis, V.; Karakonstantis, A.; Spingos, I.; Kassaras, I.; Sakkas, V.; Kouskouna, V.; Karatzetzou, A.; Pavlou, K.; Kaviris, G.; et al. First Results on the Mw=6.9 Samos Earthquake of 30 October 2020. Bull. Geol. Soc. Greece 2020, 56, 251-279. [CrossRef]

11. Onder Cetin, K.; Mylonakis, G.; Sextos, A.; Stewart, J.P. Seismological and Engineering Effects of the M 7.0 Samos Island (Aegean Sea) Earthquake; Hellenic Association of Earthquake Engineering: Athens, Greece, 2020. [CrossRef]

12. Lekkas, E.; Mavroulis, S.; Gogou, M.; Papadopoulos, G.A.; Triantafyllou, I.; Katsetsiadou, K.-N.; Kranis, H.; Skourtsos, E.; Carydis, P.; Voulgaris, N.; et al. The 30 October 2020, Mw 6.9 Samos (Greece) earthquake. Newsl. Environ. Disaster Cris. Manag. Strateg. 2020, 92-93, 1-156.

13. Triantafyllou, I.; Gogou, M.; Mavroulis, S.; Lekkas, E.; Papadopoulos, G.A.; Thravalos, M. The Tsunami Caused by the 30 October 2020 Samos (Aegean Sea) Mw7.0 Earthquake: Hydrodynamic Features, Source Properties and Impact Assessment from Post-Event Field Survey and Video Records. J. Mar. Sci. Eng. 2021, 9, 68. [CrossRef]

14. Evelpidou, N.; Karkani, A.; Kampolis, I. Relative Sea Level Changes and Morphotectonic Implications Triggered by the Samos Earthquake of 30th October 2020. J. Mar. Sci. Eng. 2021, 9, 40. [CrossRef]

15. Ganas, A.; Elias, P.; Briole, P.; Tsironi, V.; Valkaniotis, S.; Escartin, J.; Karasante, I.; Efstathiou, E. Fault responsible for Samos earthquake identified. Temblor 2020. [CrossRef]

16. Papanikolaou, D.; Nomikou, P.; Papanikolaou, I.; Lampridou, D.; Rousakis, G.; Alexandri, M. Active tectonics and seismic hazard in Skyros Basin, North Aegean Sea, Greece. Mar. Geol. 2019, 407, 94-110. [CrossRef]

17. Kreemer, C.; Blewitt, G.; Klein, E.C. A geodetic plate motion and global strain rate model. Geochem. Geophys. Geosyst. 2014, 15, 3849-3889. [CrossRef]

18. Mariolakos, I.; Papanikolaou, D. The Neogene basins of the Aegean arc from the palaeogeographic and the geodynamic point of view. In Proceedings of the International Symposium Hellenic Arc and Trench (HEAT), Athens, Greece, 8-10 April 1981; pp. 383-399.

19. Papanikolaou, D. The three metamorphic belts of the Hellenides. A review and a kinematic interpretation. Geol. Soc. Lond. Spec. Publ. 1984, 17, 551-561. [CrossRef]

20. Mascle, J.; Martin, L. Shallow structure and recent evolution of the Aegean Sea: A synthesis based on continuous reflection profiles. Mar. Geol. 1990, 94, 271-299. [CrossRef]

21. Kiratzi, A.; Louvari, E. Focal mechanisms of shallow earthquakes in the Aegean Sea and the surrounding lands determined by waveform modeling: A new database. J. Geodyn. 2003, 36, 251-274. [CrossRef]

22. Theodoropoulos, D. Geological Map of Greece, 1:50.000 Scale; Neon Karlovasi and Limin Vatheos Sheets; IGME: Athens, Greece, 1979.

23. Papanikolaou, D. Unités tectoniques et phases de déformation dans I' île de Samos, Mer Egée, Grèce. Bull. Soc. Géol. Fr. 1979, 7, 745-752. [CrossRef]

24. Papanikolaou, D. The Geology of Greece; Patakis Publ. Co.: Athens, Greece, 2015; p. 443. (In Greek)

25. Ring, U.; Laws, S.; Bernet, M. Structural analysis of a complex nappe sequence and late orogenic basins from the Aegean island of Samos, Greece. J. Struct. Geol. 1999, 21, 1575-1601. [CrossRef]

26. Roche, V.; Jolivet, L.; Papanikolaou, D.; Bozkurt, E.; Menant, A.; Rimmele, G. Slab fragmentation beneath the Aegean/Anatolia transition zone: Insights from the tectonic and metamorphic evolution of the Eastern Aegean region. Tectonophysics 2019, 754, 101-129. [CrossRef]

27. Chatzipetros, A.; Kiratzi, A.; Sboras, S.; Zouros, N.; Pavlides, S. Active faulting in the north-eastern Aegean Sea Islands. Tectonophysics 2013, 597-598, 106-122. [CrossRef]

28. Weidmann, M.; Solounias, N.; Drake, R.E.; Curtis, G.H. Neogene stratigraphy of the eastern basin, Samos Island, Greece. Geobios 1984, 17, 477-490. [CrossRef]

29. Angelier, J. Sur l'alternance mio-quaternaire de mouvements extensifs et compressifs en Egee orientale: L' ile de Samos. (Grece). C. R. Acad. Sci. 1976, 283, 463-466.

30. Aksu, A.E.; Piper, D.J.W.; Konuk, T. Quaternary growth patterns of Buyuk Menderes and Kuyuk Menderes deltas, western Turkey. Sediment. Geol. 1987, 52, 227-250. [CrossRef]

31. Taymaz, T.; Jackson, J.A.; McKenzie, D. Active tectonics of the north and central Aegean Sea. Geophys. J. Int. 1991, 106, 433-490. [CrossRef]

32. Seyitoglu, G.; Scott, B.C. The cause of NS extensional tectonics in western Turkey: Tectonic escape vs back-arc spreading vs orogenic collapse. J. Geodyn. 1996, 22, 145-153. [CrossRef]

33. Yilmaz, Y.; Genç, Ş.C.; Gürer, F.; Bozcu, M.; Yilmaz, K.; Karacik, Z.; Altunkaynak, Ş.; Elmas, A. When did the western Anatolian grabens begin to develop? Geol. Soc. Lond. Spec. Publ. 2000, 173, 353-384. [CrossRef]

34. Stiros, S.C.; Laborel, J.; Laborel-Deguen, F.; Papageorgiou, S.; Evin, J.; Pirazzoli, P.A. Seismic coastal uplift in a region of subsidence: Holocene raised shorelines of Samos Island, Aegean Sea, Greece. Mar. Geol. 2000, 170, 41-58. [CrossRef] 
35. Papanikolaou, D.; Nomikou, P.; Alexandri, S.; Ballas, D. Morphotectonic structure of the western part of the North Aegean basin based on swath bathymetry. Mar. Geol. 2002, 190, 465-492. [CrossRef]

36. Papanikolaou, D.; Nomikou, P.; Alexandri, S. Active faulting in the North Aegean basin. Geol. Soc. Am. Spec. Pap. 2006, 409, 189-209.

37. Ocakoglu, N.; Demirbag, E.; Kuscu, I. Neotectonic structures in the area offshore Alacati, Goganbey and Kusadasi (Western Turkey): Evidence of strike-slip faulting in the Aegean extensional province. Tectonophysics 2004, 391, 67-83. [CrossRef]

38. Ktenas, C. Decouverte du Pliocene inferieur marin dans l' ile de Nikaria. C. R. Acad. Sci. 1927, 184, 756-758.

39. Georgalas, G. Les terrasses littorales de la cote sud-oriental de l' ile de Nikaria (Mer Egee). Prakt. Acad. Athenes 1953, $28,425-434$.

40. Papanikolaou, D. Contribution to the geology of Ikaria Island, Aegean Sea. Ann. Géol. Pays Hell. 1978, 29, 1-28. (In Greek)

41. Papanikolaou, D. Les écailles de Thymaena: Témoins d' un mouvement tectonique miocène vers I'intérieur de I'arc égéen. C. $R$. Acad. Sci. 1980, 290, 307-310.

42. Nomikou, P.; Hubscher, C.; Papanikolaou, D.; Farangitakis, P.; Runhau, M.; Lambridou, D. Expanding extension, subsidence and lateral segmentation within the Santorini-Amorgos basins during Quaternary: Implications for the 1956 Amorgos events, central-south Aegean Sea, Greece. Tectonophysics 2018, 722, 138-153. [CrossRef]

43. Alexandri, M.; Papanikolaou, D.; Nomikou, P.; Ballas, D. Geological Structure of the Myrtoon Basin (Aegean Sea) Based on Swath Bathymetry. In Rapport Commission International Pour L'exploration Scientifique de la Mer Mediterranee; CIESM: Madrid, Spain, 2001; Volume 36.

44. Nomikou, P.; Papanikolaou, D.; Alexandri, M.; Sakellariou, D.; Rousakis, G. Submarine volcanoes along the Aegean Volcanic Arc. Tectonophysics 2013, 597-598, 123-146. [CrossRef]

45. Wells, D.I.; Coppersmith, K.J. New empirical relationships among magnitude, rupture length, rupture area and surface displacement. Bull. Seismol. Soc. Am. 1994, 84, 974-1002.

46. Papazachos, B.C.; Papaioannou Ch, A.; Papazachos, C.B.; Savvaidis, A.A. Atlas of isoseismal maps for strong earthquakes in Greece and surrounding area. Publ. Geophys. Lab. Univ. Thessalon. 1997, 4, 200.

47. Benetatos, C.; Kiratzi, A.; Ganas, A.; Ziazia, M.; Plessa, A.; Drakatos, G. Strike-slip motions in the Gulf of Siğaçik (western Turkey): Properties of the 17 October 2005 earthquake seismic sequence. Tectonophysics 2006, 426, 263-279. [CrossRef] 